\title{
Piotr Bojarski
}

\section{SPRAWOZDANIE Z KONFERENCJI NAUKOWEJ NIE TYLKO PLEBISCYT. ROK 1920 NA WARMII, MAZURACH, W POLSCE I EUROPIE}

W dniach 22-23 października 2020 r. w budynku Domu Polskiego, siedzibie Instytutu Pólnocnego im. Wojciecha Kętrzyńskiego w Olsztynie odbyła się konferencja naukowa zatytułowana Nie tylko plebiscyt. Rok 1920 na Warmii, Mazurach, w Polsce $i$ Éuropie. Sesja została zorganizowana przez Instytut Pólnochy im. Wojciecha Kętržyńskiego w Olsztynie, Oddział Polskiej Akademii Nauk w Olsztynie i Białymstoku z siedzibą w Olsztynie oraz Regionalny Ośrodek Debaty Międzynarodowej w Olsztynie. Wydarzenie patronatem honorowym objęło Ministerstwo Kultury i Dziedzictwa Narodowego. Patronatu medialnego udzieliło Radio Olsztyn S.A.

Wybór daty i tematyki konferencji miał charakter nieprzypadkowy. W $2020 \mathrm{r}$. minęło sto lat od wydarzeń kluczowych dla kształtu odrodzonego państwa polskiego. Rok 1920 to dla Warmii, Mazur i Powiśla czas plebiscytu - głosowania, które w ówczesnych warunkach geopolitycznych nie mogło zakończyć się sukcesem. Państwo polskie większość posiadanych wówczas sił i środków zaangażowało $\mathrm{w}$ walkę z bolszewikami. W wyniku zwycięskich bitew - warszawskiej i niemeńskiej udało się uratować suwerenność Rzeczypospolitej i zakończyć działania wojenne na wschodzie.

Kolejnym istotnym elementem formowania się II Rzeczypospolitej były powstania śląskie oraz plebiscyt przeprowadzony na obszarze Górnego Śląska już w 1921 r. Ważną kwestię stanowił również spór o Śląsk Cieszyński, Spisz i Orawę pomiędzy Polską i Czechosłowacją. Wszystkie wyżej wymienione zagadnienia zostały poruszone podczas październikowej sesji.

Konferencję, w imieniu dyrektora Instytutu Północnego dr. Jerzego Kiełbika, otworzył prof. dr hab. Stanisław Achremczyk - historyk od wielu lat związany z Ośrodkiem Badań Naukowych im. W. Kętrzyńskiego, prezes Towarzystwa Naukowego im. W. Kętrzyńskiego w Olsztynie. Profesor Achremczyk witając uczestników przybliżył historię Domu Polskiego - niezwykle ważnego miejsca na mapie Olsztyna - nie tylko w okresie plebiscytowym. 
Pierwszą część obrad rozpoczął prof. dr hab. Wojciech Polak (Uniwersytet Mikołaja Kopernika w Toruniu) - przewodniczący Rady Programowej Instytutu Północnego, który wygłosił referat pt. Walka o Lwów w latach 1918-1920 jako przykład solidarności Polaków z różnych zaborów w staraniach o odzyskanie niepodległości.

Kolejne referaty wygłosili przedstawiciele Instytutu Śląskiego w Opolu dr hab. Piotr Pałys oraz dr Bernard Linek. Pierwszy z prelegentów w swoich rozważaniach skoncentrował się na problematyce niedoszłego plebiscytu na Śląsku Cieszyńskim. Doktor Bernard Linek z kolei przybliżył zebranym kwestie związane z plebiscytem na Górnym Śląsku. Następny prelegent - dr hab. Zbigniew Kudrzycki (Towarzystwo Naukowe im. W. Kętrzyńskiego w Olsztynie) w swoim wystąpieniu ukazał zagadnienie plebiscytu na Warmii, Mazurach i Powiślu na forum Sejmu Ustawodawczego w latach 1919-1920.

Następne referaty odnosiły się do szeroko rozumianej problematyki pomocy udzielanej społeczności ziem plebiscytowych przez ludność Lubelszczyzny. Doktor Elżbieta s. Monika Albiniak ze Zgromadzenia Sióstr Opatrzności Bożej omówiła dzieje Akademickiego Komitetu Obrony Ziem Plebiscytowych Warmii, Mazur i Górnego Śląska, działającego na Uniwersytecie Lubelskim. Kwestie pomocy kierowanej $\mathbf{z}$ Lubelszczyzny na ziemie plebiscytowe podjął także Andrzej Albiniak - badacz niezależny z Janowa Lubelskiego. Pierwszy dzień sesji zamknął swoim wystąpieniem mgr Adrian Talarek (Uniwersytet Humanistyczno-Przyrodniczy w Częstochowie), który przybliżył realia społeczno-polityczne panujące w rejonie częstochowskim w czasie wojny polsko-bolszewickiej.

Po zakończeniu obrad referenci, wraz z pracownikiem Instytutu Północnego dr Emilią Figurą-Osełkowską, udali się na zwiedzanie olsztyńskiego Starego Miasta. Jego zwieńczeniem była wizyta w Muzeum Warmii i Mazur połączona z oprowadzeniem kuratorskim po wystawie Wersal, plebiscyt $i$ co dalej na Warmii i Mazurach? Ekspozycja została przygotowana przez pracowników Muzeum - dr. Sebastiana Mierzyńskiego i dr Małgorzatę Gałęziowską.

Drugi dzień konferencji zainaugurowało wystąpienie dr Emilii Figury-Osełkowskiej z Instytutu Północnego dotyczące pomników plebiscytowych na Warmii i Mazurach. Duże zainteresowanie uczestników konferencji wzbudził bogaty materiał ikonograficzny zebrany przez autorkę, ukazujący nie tylko „klasyczne” pomniki plebiscytowe, ale także inne obiekty (dęby, pamiątkowe głazy) mające podkreślać rozmiary niemieckiego zwycięstwa z lipca 1920 r.

Kolejna referentka - dr Justyna Liguz, reprezentująca Muzeum w Kwidzynie, przybliżyła kulisy wizyty Stefana Żeromskiego, Jana Kasprowicza i Władysława Kozickiego na Powiślu w 1920 roku. Swoim wystąpieniem dr Liguz uzupełniła treści zawarte w publicystycznym zbiorze Inter Arma, prezentującym wrażenia autora „Przedwiośnia” m.in. z pobytu na Powiślu. 
Sesję zwieńczyły wystąpienia mgr Magdaleny Łowkiel (Salon Muzyczny im. Feliksa Nowowiejskiego w Barczewie) oraz dr. Sławomira Maksymowicza - reprezentanta Archiwum Państwowego w Olsztynie. Magdalena Łowkiel przybliżyła zebranym historię powstania Hymnu Warmińskiego, a Sławomir Maksymowicz podjął niezwykle interesującą problematykę wpływu przemocy stosowanej przez Niemców wobec Warmiaków i Mazurów na wynik plebiscytu.

Niezwykle interesujący element konferencji stanowił przedpremierowy pokaz filmu Spuścizna czyli Saga mazurskiego rodu Leyk wyreżyserowanego przez Adama Błaszczoka, w którym wykorzystano materiały ze Zbiorów Specjalnych Instytutu Północnego im. Wojciecha Kętrzyńskiego. Projekcję swoją obecnością uświetnił potomek filmowych bohaterów, Wiktor Marek Leyk - pełnomocnik marszałka województwa warmińsko-mazurskiego ds. mniejszości narodowych i etnicznych.

Dużym zainteresowaniem uczestników konferencji cieszyły się także wystawy Olsztyńska Solidarność 1980-2020 oraz Dom Polski 1920-2020, przygotowane przez historyków z Instytutu Północnego i eksponowane obecnie w Domu Polskim.

Podsumowania konferencji dokonał dr Jerzy Kiełbik - dyrektor Instytutu Północnego im. Wojciecha Kętrzyńskiego w Olsztynie który dziękując za udzial podkreślit, że pomimo ograniczeń wynikających z panującej pandemii koronawirusa konferencja odbyła się zgodnie z planem. Spotkanie stanowiło jednocześnie doskonałą okazję do prezentacji wyników najnowszych badań naukowych oraz płaszczyznę wymiany poglądów zarówno w ramach obrad jak i podczas rozmów kuluarowych.

Ze względu na obowiązujące obostrzenia, w sesji uczestniczyli jedynie referenci oraz część pracowników Instytutu. Dzięki zaangażowaniu zespołu Instytutu Północnego udało się przeprowadzić transmisję na żywo na platformie Youtube, która w ciągu dwóch dni obrad zgromadziła około 300 widzów. 